\title{
Biology of the annular seabream, Diplodus annularis (Sparidae), in coastal waters of the Canary Islands
}

\author{
By J. G. Pajuelo and J. M. Lorenzo \\ Departamento de Biologia, Universidad de Las Palmas de Gran Canaria, Campus Universitario de Tafira,
} Las Palmas de Gran Canaria, Canary Islands, Spain

\begin{abstract}
Summary
The biology of the Canary Islands annular seabream Diplodus annularis (Linnaeus 1758) was studied from samples collected between January and December 1998. Fish ranged from 82 to $209 \mathrm{~mm}$ total length in size and from 8.7 to $137.1 \mathrm{~g}$ in weight. The mean length showed an increase with increasing water depth. Males showed a negative allometric growth and females isometric growth. The species was characterized by protandric hermaphroditism. The overall sex ratio was unbalanced in favour of males $(1: 0.79)$. The reproductive season extended from January to May, with a peak in spawning activity in March-April. Males reached maturity at a smaller length (103 mm, 1-year-old) than females (128 mm, 2-year-old). Fish aged $0-6$ years were found. The von Bertalanffy growth parameters for all individuals were: $\mathrm{L}_{\infty}=247.9 \mathrm{~mm}$, $\mathrm{k}=0.268$ years $^{-1}$, and $\mathrm{t}_{0}=-0.879$ years.
\end{abstract}

\section{Introduction}

In the Canary Islands, the family Sparidae is represented by 10 genera, one of which is the genus Diplodus Rafinesque 1810 . Only five species of this genus are found in this area, one of which is the annular seabream Diplodus annularis (Linnaeus 1758).

Annular seabream is a demersal marine fish found in groups on sandy bottoms and seagrass beds at depths ranging from 0 to $50 \mathrm{~m}$. This species is distributed from the Gulf of Biscay to Gibraltar, and around Madeira and the Canary Islands. It is also present in the Mediterranean and the Black Sea (Bauchot and Hureau 1990; Harmelin-Vivien et al. 1995).

In the Canary Islands, annular seabream is commercially important. Despite this, no information on this species has been published. The aim of the present work is to determine the sexuality, reproduction, age, and growth of the Canary Islands annular seabream population.

The findings of this study are important as they can be used to develop a management strategy for the species. The importance of this work is enhanced by the fact that published information on the biology and ecology of annular seabream is very scarce throughout the world. Previously only aspects on seabream morphometrics (Dremière 1983), sexuality and reproduction (D'Ancona 1945, 1949; Salekhova 1961, 1970; Lissia-Frau 1968; Dremière 1983) and feeding (Rosecchi 1985) have been described.

\section{Materials and methods}

A total of 419 specimens of annular seabream, collected fortnightly by a random stratified method from the commer- cial catches of the artisanal fleet between January and December 1998, was studied. Fish were caught with pots deployed on the bottom at depths of 1-50 m off Gran Canaria (Canary Islands).

Analysis of the samples was completed immediately after landing. For each individual, total length (TL) was measured to the nearest $\mathrm{mm}$ and total weight (TW) to the nearest $0.1 \mathrm{~g}$. The sex and the stage of maturation were determined macroscopically and the weight of the gonads was measured to the nearest $0.01 \mathrm{~g}$. The stages of maturation were classified as follows: I, immature; II, resting; III, ripe; IV, ripe and running; and V, spent. Sagittal otoliths were extracted, cleaned, and stored dry.

The total length-total weight relationship was calculated over the entire period by applying a linear regression (Ricker, 1973). The mean length of fish by depth strata (0-10 and 10$50 \mathrm{~m}$ ) was calculated.

The sex ratios (males: females) for the entire sample and for different size classes $(10 \mathrm{~mm})$ were estimated. The reproductive period was established following the evolution of the maturity stages and the evolution of the gonadosomatic index. The length at first maturity (length at which $50 \%$ of the fish had become mature) was estimated by means of a logistic function that was fitted to the proportion of the mature individuals (stages III, IV, and V) using a nonlinear regression (Saila et al. 1988).

Age was determined by interpreting growth rings on the otoliths. Whole otoliths were placed in a watch glass with a blackened bottom and containing glycerine and examined under a compound microscope with reflected light. Counts for each specimen were performed twice and only coincident readings were accepted. An index of average percentage error, developed by Beamish and Fournier (1981), was used to compare the precision of age determinations. Ageing was validated indirectly by examination of monthly changes in appearance of the edges of the otoliths (Morales-Nin 1987). The von Bertalanffy growth curve was fitted to data of the resulting age-length key by means of the Marquardt's algorithm for nonlinear least squares parameter estimation (Saila et al. 1988).

\section{Results}

Fish ranged in size from 82 to $209 \mathrm{~mm} \mathrm{TL}$ and weighed between 8.7 and $137.1 \mathrm{~g}$. Length of males ranged from 89 to $206 \mathrm{~mm}$ and mass from 9.3 to $114.7 \mathrm{~g}$. Female length ranged between 94 and $209 \mathrm{~mm}$ and mass between 13.2 and $137.1 \mathrm{~g}$. Intersexual individuals were found at sizes of $122-143 \mathrm{~mm}$ and 
Table 1

Parameters of the length-weight relationship for Canary Islands males, females and all fish of $D$. annularis and the possibility of isometry tested by Student's t-test (January-December 1998)

\begin{tabular}{lllllll}
\hline & $\mathrm{a}$ & $\mathrm{b}$ & $\mathrm{se}(\mathrm{b})$ & $\mathrm{n}$ & $\mathrm{r}^{2}$ & t-test \\
\hline Males & 0.00002881 & 2.830138 & 0.088334 & 194 & 0.985 & $1.90^{*}$ \\
Females & 0.00002265 & 2.917807 & 0.191079 & 155 & 0.979 & 0.43 \\
All fish & 0.00002116 & 2.941783 & 0.059411 & 419 & 0.984 & 0.97 \\
\hline
\end{tabular}

$*\left(t>t_{0.05, n}>150=1.65\right)$.

masses of $33.9-51.7 \mathrm{~g}$. Immature individuals ranged from 82 to $119 \mathrm{~mm}$ in length and from 8.7 to $29.6 \mathrm{~g}$ in weight. The parameters of the total length to total weight relationship for males and females separately, and for the population as a whole, are given in Table I. Significant differences in the allometric coefficient of the regression was found between sexes ( $t$-test, $t=6.01>t_{0.05,347}=1.65$ ). Males exhibited negative allometric growth and females isometric growth.

Fish were caught at depths of $3-47 \mathrm{~m}$, mainly between 5 and $30 \mathrm{~m}$. The mean length showed an increase with increasing depth. The mean length for depths below $10 \mathrm{~m}$ was $98 \mathrm{~mm}$, whilst in depths above $10 \mathrm{~m}$ it was $132 \mathrm{~mm}$.

Of the total number of fish examined, $194(46.3 \%)$ were males, $155(37.0 \%)$ females, and $14(3.3 \%)$ intersexual individuals. The sex of the remaining $56(13.4 \%)$ fish could not be identified macroscopically because they were immature and had very thin, translucent gonads. The overall ratio of males to females was $1: 0.79$. A chi-square test revealed this to be significantly different from a $1: 1$ ratio (Table 2). Males predominated in smaller size classes and females in larger size classes. Intersexual individuals were intermediate in size between males and females. Sex ratios of males and females by size classes departed significantly from the $1: 1$ ratio for most classes, except for the mid-size seabream $(130-140 \mathrm{~mm})$ (Table 1).

Males and females with ripe gonads (stage III) were recorded between January and March, being dominant in February. Ripe and running fish (stage IV) appeared in February and became dominant in March and April. Spent

Table 2

Number of male, female, intersexual and immature individuals of Canary Islands $D$. annularis by $10-\mathrm{mm}$ size class and sex ratio tested by chi-square analysis (January-December 1998)

\begin{tabular}{|c|c|c|c|c|c|c|}
\hline $\begin{array}{l}\text { Length } \\
\text { (mm) }\end{array}$ & Males & Females & $\begin{array}{l}\text { Inter- } \\
\text { sexuals }\end{array}$ & Immatures & $\begin{array}{l}\text { Sex } \\
\text { ratio }\end{array}$ & $y^{2}$ \\
\hline 80 & & & & 6 & & \\
\hline 90 & 9 & 1 & & 21 & $1: 0.11$ & $6.40^{*}$ \\
\hline 100 & 21 & 2 & & 17 & $1: 0.10$ & $7.84^{*}$ \\
\hline 110 & 39 & 7 & & 10 & $1: 0.18$ & $22.26^{*}$ \\
\hline 120 & 49 & 12 & 1 & 2 & $1: 0.25$ & $22.44^{*}$ \\
\hline 130 & 27 & 16 & 9 & & $1: 0.59$ & 2.81 \\
\hline 140 & 16 & 25 & 4 & & $1: 1.56$ & 1.98 \\
\hline 150 & 10 & 21 & & & $1: 2.10$ & $3.90^{*}$ \\
\hline 160 & 7 & 17 & & & $1: 2.43$ & $4.16^{*}$ \\
\hline 170 & 6 & 15 & & & $1: 2.50$ & $3.85^{*}$ \\
\hline 180 & 4 & 12 & & & I: 3.00 & $4.00^{*}$ \\
\hline 190 & 3 & 11 & & & $1: 3.66$ & $4.57^{*}$ \\
\hline 200 & 2 & 9 & & & $1: 4.50$ & $4.45^{*}$ \\
\hline 210 & 1 & 7 & & & $1: 7.00$ & $4.50^{*}$ \\
\hline Total & 194 & 155 & 14 & 56 & $1: 0.79$ & $4.35^{*}$ \\
\hline
\end{tabular}

${ }^{*}\left(\chi^{2}>\chi_{t}^{2} 1.0 .05=3.84\right)$.
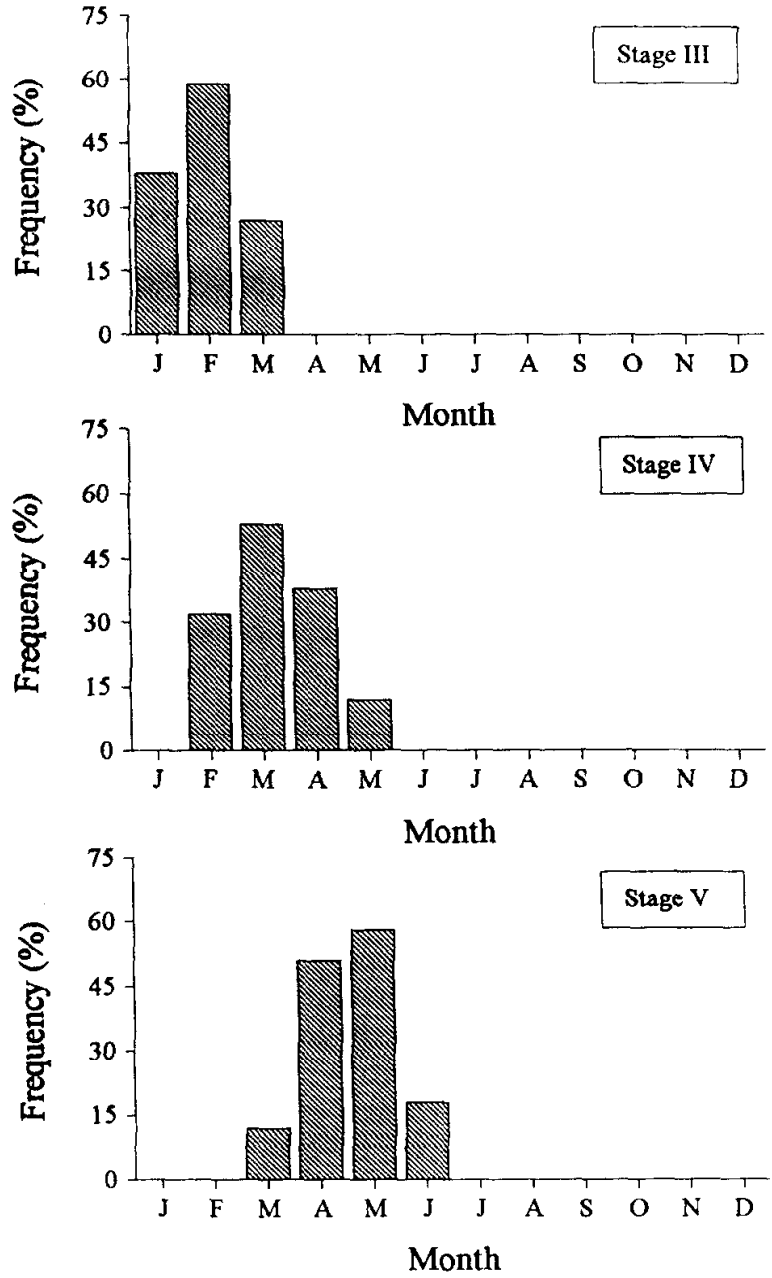

Fig. 1. Monthly evolution of the maturity stages for Canary Islands D. annularis males and females (January-December 1998)

fish (stage V) were recorded from March to June (Fig. 1). The gonadosomatic index showed the same temporal variation pattern for males and females. Lower values for males than for females were observed. The highest values occurred between February and May, with a maximum in MarchApril (Fig. 2).

Figure 3 shows the sexual maturity ogives for males and females separately. Significant differences in length at first maturity were found between males and females (t-test, $t=5.17>t_{005,347}=1.65$ ). A total of $50 \%$ of males and females became mature at 103 and $128 \mathrm{~mm}$, respectively. Individuals smaller than $90 \mathrm{~mm}$ showed little evidence of sexual activity.

Of the otoliths examined, $371(88.5 \%)$ were readable and used for the study of age and growth. The value of the index of average percentage error was only $2.9 \%$. Annual marks were equal in both the anterior and lateral otolith fields. Annuli were apparent, whereas non-annual marks usually were not apparent. Edge zone analysis showed that one annulus was formed per year (Fig. 4). The percentage of otoliths with an opaque edge was high in the months from May to October, and between June and August in particular.

Fish aged 0-6 years were recorded (Table 3 ). The parameters of the von Bertalanffy growth curve for males, females and all individuals are shown in Table 4. Significant differences 

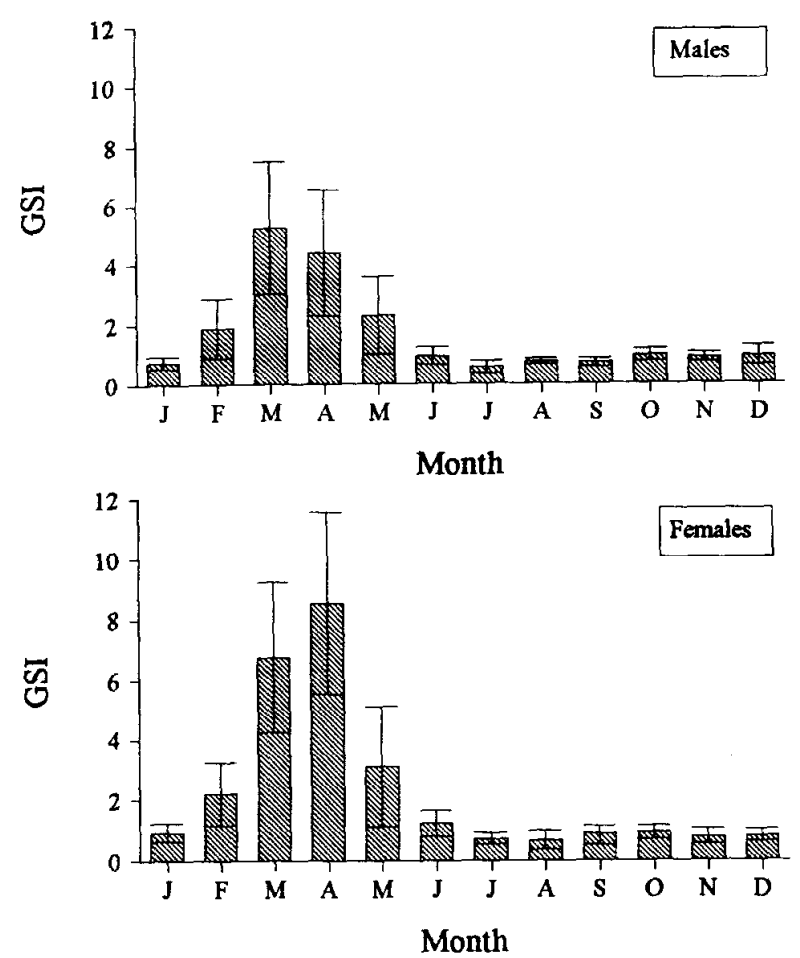

Fig. 2. Monthly evolution of the gonadosomatic index (GSI) for Canary Islands $D$. annularis males and females (January-December 1998)
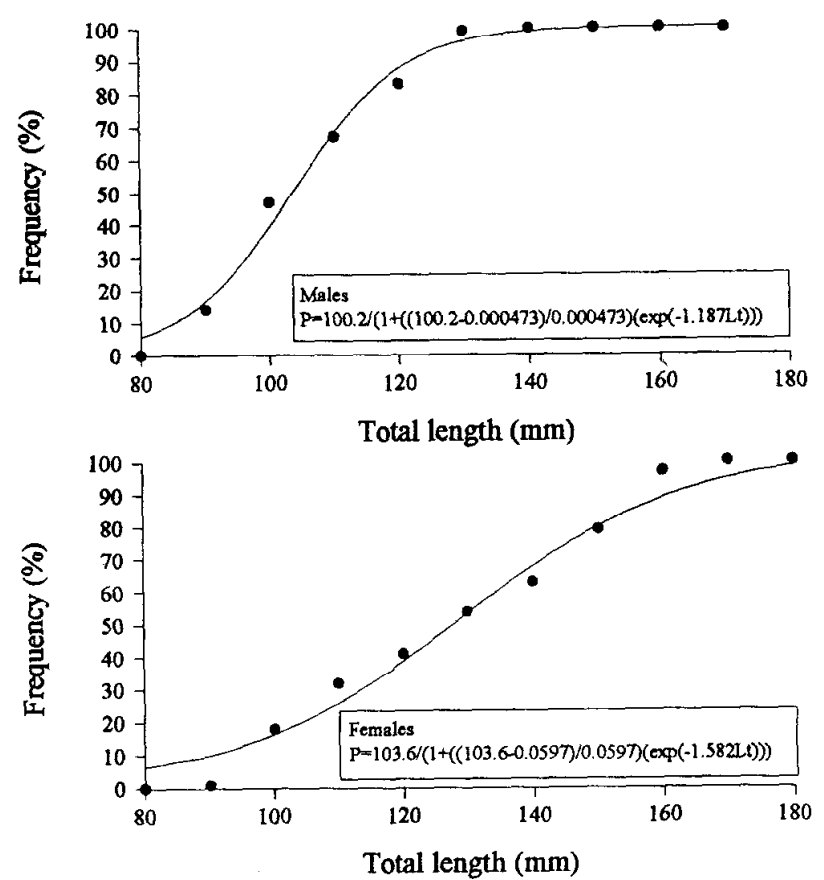

Fig. 3. Sexual maturity ogives for Canary Islands D. annularis males and females (January-December 1998)

in the growth parameters were found between males and females (Hotelling's $\mathrm{T}^{2}$-test, $\mathrm{T}^{2}=12.32>\mathrm{T}_{0}{ }^{2}{ }_{0.05,3,308}=7.93$ ). Males grew at a slightly slower rate than females.

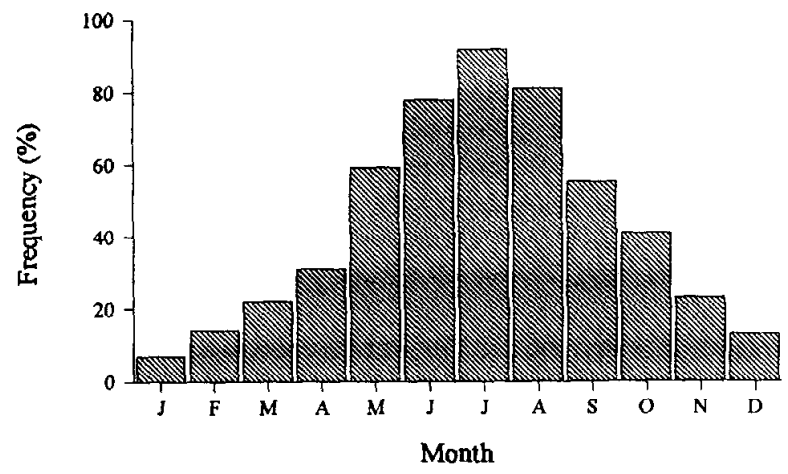

Fig. 4. Monthly percentages of otoliths with opaque edge for $D$. annularis of the Canary Islands (January-December 1998)

Table 3

Age length distribution for all Canary Islands $D$. annularis fish (January-December 1998)

\begin{tabular}{|c|c|c|c|c|c|c|c|}
\hline \multirow[b]{2}{*}{ Size $(\mathrm{mm})$} & \multicolumn{7}{|c|}{ Age group (year) } \\
\hline & 0 & I & II & III & IV & V & VI \\
\hline 80 & 6 & & & & & & \\
\hline 90 & 19 & 8 & & & & & \\
\hline 100 & 14 & 20 & & & & & \\
\hline 110 & 13 & 27 & 4 & & & & \\
\hline 120 & 8 & 12 & 36 & & & & \\
\hline 130 & 1 & 9 & 37 & & & & \\
\hline 140 & & 5 & 23 & 12 & & & \\
\hline 150 & & 1 & 11 & 16 & & & \\
\hline 160 & & & 4 & 20 & & & \\
\hline 170 & & & 2 & 14 & 7 & 1 & \\
\hline 180 & & & & 4 & 9 & & \\
\hline 190 & & & & & 6 & 5 & \\
\hline 200 & & & & & 1 & 7 & 3 \\
\hline 210 & & & & & & 2 & 4 \\
\hline $\mathrm{n}$ & 61 & 82 & 117 & 66 & 23 & 15 & 7 \\
\hline $\mathrm{x}$ & 93.4 & 110.6 & 134.3 & 159.4 & 181.5 & 199.8 & 205.1 \\
\hline SD & 1.0 & 1.9 & 2.3 & 2.3 & 2.2 & 2.1 & 1.7 \\
\hline
\end{tabular}

Table 4

Estimatcs of von Bertalanffy growth parameters for Canary Islands males, females and all fish of $D$. annularis (January-December 1998)

\begin{tabular}{llllll}
\hline & $\mathrm{L}_{\infty}(\mathrm{mm})$ & $\mathrm{k}\left(\right.$ year $\left.^{-1}\right)$ & $\mathrm{l}_{0}($ year $)$ & $\mathrm{n}$ & $\mathrm{r}^{2}$ \\
\hline Males & 245.7 & 0.271 & -0.884 & 173 & 0.976 \\
Females & 250.2 & 0.243 & -0.901 & 139 & 0.961 \\
All fish & 247.9 & 0.268 & -0.879 & 371 & 0.985 \\
\hline
\end{tabular}

\section{Discussion}

In the Canarian archipelago, the annular seabream $D$. annularis is found between 3 and $47 \mathrm{~m}$ depth. Below this depth, it is replaced by other species of the genus Diplodus present in the area, such as D. cervinus, D. vulgaris, D. puntazzo and $D$. sargus. The present work revealed that juveniles inhabit the nursery in shallow water areas $(<10 \mathrm{~m})$. The presence of juveniles in shallow waters has also been observed in other sparids present in the Canary Islands, such as Spondyliosoma cantharus (Pajuelo and Lorenzo 1999) and Pagellus acarne (Pajuelo and Lorenzo 2000).

Diverse expressions of sexuality are found in the species of the family Sparidae. In this family, protogyny, protandry, 
rudimentary hermaphroditism and true gonochorism were recognized (Buxton 1989). This variability is probably linked to the peculiar configuration of the gonad, an ovotestis, that is characteristic of all species of the family (Buxton and Garratt, 1990). The annular seabream of the Canary Islands exhibit protandric hermaphroditism; the presence of individuals with ovotestes and the predominance of males at smaller sizes confirm this. This characteristic has also been pointed out in other studies which deal with the sexuality of the species (Salekhova 1961, 1970). The appearance of intersexual individuals in a relatively short length range $(120-140 \mathrm{~mm})$ suggests that the sex conversion occurs simultaneously for all males. The scarcity of individuals with both developed ovarian and testicular tissues indicates a rather brief transitory phase between sexes for each individual. The presence of males in the largest size classes suggests that sex conversion is not essential for all individuals, and the presence of females in the smallest size classes shows the existence of primary females (Sadovy and Shapiro 1987).

The sex structure of the Canary Islands annular seabream population, with a predominance of males over females, is mainly determined by the nature of the sexual change. Related to this, Smale (1988) indicated that the sex ratios of protandric sparids may be skewed toward males. Sadovy and Shapiro (1987) indicated that protandric species have a bimodal size or age frequency distribution, where the modal size of males is less than the modal size of females. In the present study, the length range of males almost completely overlaps with that of females because some of the females develop from a functional male phase, while others develop directly as females.

The annular seabream off the Canary Islands have a definite reproductive period, extending from January to May, with maximal gonadal activity in March-April. In the western Mediterranean spawning takes place between April and June (Dremière 1983), in the northern Adriatic between May and August (Lissia-Frau 1968), and in the Black Sea between July and September (Salekhova 1961, 1970). Thus, there is a delay in the time of spawning among the different populations from the eastern Atlantic to the Black Sea.

The difference observed in sexual maturity between males and females may be explained adequately by protandry. Males attain maturity at 1 year, and females at 2 years. Dremière (1983) pointed out that this species also attains sexual maturity at 1 year in the western Mediterranean.

The length-weight relationship reveals that females are heavier than males for a given length. This may be explained by protandry, because males predominated in smaller size classes and females in larger size classes.

Otoliths of the annular seabream of the Canarian archipelago show the ring pattern common to teleost fishes. One opaque and one translucent ring are laid down each year on the otoliths, allowing age determination with relative ease. These rings are deposited owing to alternating periods of rapid and slow growth (Williams and Bedford 1974). Seasonal growth cycles might be related to physiological changes produced by the influence of temperature, feeding regime and reproductive cycle. In the Canary Islands, the formation of opaque and translucent rings in the otoliths of annular seabream occurs during summer and winter months, respectively. The opayue rings are formed when the temperature reaches the highest values $\left(24^{\circ} \mathrm{C}\right)$ and food is more abundant; translucent rings are formed when the temperature reaches the lowest values $\left(18^{\circ} \mathrm{C}\right)$ and breeding occurs in the species. The evidence currently available suggests that a seasonal tempera- ture difference of $6{ }^{\circ} \mathrm{C}$ might be sufficient to cause ring formation (Morales-Nin and Ralston 1990). During the reproductive period, the metabolic energy seems to be diverted from growth, causing the formation of thin increments which in turn are reflected in translucent seasonal growth rings.

Annular seabream grow rapidly during the first year of life, attaining approximately $50 \%$ of their maximum length. After the first year, the annual growth rate drops rapidly, related to sexual maturity, since in the area studied individuals are mature by the first year of life. Hence, energy seems to be diverted to reproduction, with less energy available for somatic growth.

The difference in growth between sexes, with females growing at a slightly faster rate than males, is a characteristic of the protandric species. Alekseev (1983) and Shapiro (1984) pointed out that the mean size of sex-reversed fish is slightly larger than males of the same age. Therefore, the difference in size between males and females of the same age cannot be considered as evidence of an intersexual difference in growth rates because males and females are the same specimens at different stages of sexual succession and, possibly, the largest males in an age group are the first to revert.

\section{References}

Alekseev, F. E., 1983: Hermaphroditism in porgies (Perciformes, Sparidae). 2. Sexual structured of the populations mechanism of its formation and evolution in scups, Pagrus pagrus, P. orphus, $P$. ehrenbergi, P. auriga. J. Ichthyol. 23, 61-73.

Bauchot, M. L.; Hureau, J. C., 1990: Sparidae. In: Check-List of the Fishes of the Eastern Tropical Atlantic. Clofeta II. Eds: J. C. Quero; J. C. Hureau; C. Karrer; A. Post; L. Saldanha, UNESCO, Paris, pp. 790-812.

Beamish, R. J.; Fournier, D. A., 1981: A method for comparing the precision of a set of age determination. Can. J. Fish. Aquat. Sci. 38, 982-983.

Buxton, C. D., 1989: Protogynous hermaphroditism in Chrysoblephus laticeps (Cuvier) and C. cristiceps (Cuvier) (Teleostei: Sparidae). S. Afr. J. Zool. 24, 212-216.

Buxton, C. D.; Garratt, P. A., 1990: Alternative reproductive styles in seabreams (Pisces: Sparidae). Env. Biol. Fish. 28, 113-124.

D'Ancona, U., 1945: Hermaphroditism in the genus Diplodus (Sin. sargus; Teleostei). Boll. Soc. Ital. Biol. Sper. 22, 653-655.

D'Ancona, U., 1949: Hermaphroditism and sex change in Teleostej. Experimentia 5, 381-389.

Dremière, P. Y., 1983: Paramètres biologiques et dynamiques disponibles sur les principaux stocks halieutiques du Golfe du Lion. FAO, Rapp. Pêches 227, 115-127.

Harmelin-Vivien, M. L.; Harmelin, J. G.; Leboulleux, V., 1995: Microhabitat requirements for settlement of juvenile sparid fish on Mediterranean rocky shores. Hydrobiologia 300-301, 309-320.

Lissia-Frau, A. M., 1968: Le manifestazioni della sessualità negli Sparidi (Teleostei, Perciformes). Studi Sassaresi 46, 222-243.

Morales-Nin, B., 1987: Métodos de determinación de la edad en los osteictios en base a estructuras de crecimiento. Inf. Téc. Inst. Inv. Pesq. 143, $1-30$.

Morales-Nin, B.; Ralston, S., 1990: Age and growth of Lutianus kasmira (Forskal) in Hawaiian waters. J. Fish. Biol. 36, 191--203.

Pajuelo, J. G.; Lorenzo, J. M., 1999: Life history of black seabream, Spondyliosoma cantharus, off the Canary Islands, Central-east Atlantic. Env. Biol. Fish. 54, 325-336.

Pajuelo, J. G.; Lorenzo, J. M., 2000: Reproduction, age, growth and mortality of axillary seabream, Pagellus acarne (Sparidae), from the Canarian archipelago. J. Appl. Ichthyol. 16, 41-47.

Ricker, W. E., 1973: Linear regressions in fishery research. J. Fish. Res. Board Can. 30, $409-434$.

Rosecchi, E., 1985: L'alimentation de Diplodus anmularis, Diplodus sargus, Diplodus vulgaris et Sparus aurata (Pisces: Sparidae) dans le Golfe du Lion et les lagunes littorales. Rev. Trav. Inst. Pêches Marit. Nantes 49, 121-141.

Sadovy, I.; Shapiro, D. Y., 1987: Criteria for the diagnosis of hermaphroditism in fishes. Copeia 1, 136-156. 
Saila, S. B.; Recksiek, C. W.; Praguer, H., 1988: Basic fishery science programs. A compendium of microcomputer programs and manual of operation. Devel. Aquacult. Fish. Sci. 18, 1-230.

Salekhova, L. P., 1961: Hermaphroditism of annular bream Diplodus annularis (L.). Trudy Sevastopol Biol. Stat. 14, 257-268.

Salekhova, L. P., 1970: Size-sex ratio, sex differentiation and hermaphroditism in the fishes. In: Reproduction and Ecology of the Mass-Scale Fishes of the Black Sea at Early Ontogenetic Stages. Naukova Dumka Press, Kiev, p. 211.

Shapiro, D. Y., 1984: Sex reversal and sociodemographic process in coral reef fishes. In: Fish Reproduction, Strategies and Tactics. Eds: G. W. Potts; R. J. Woottom, Academic Press, London, pp. 103-117.
Smale, M. J., 1988: Distribution and reproduction of the reef fish Pctrus rupestris (Pisces: Sparidae) off the coast of South Africa. S. Afr. J. Zool. 23, 272-287.

Williams, T.; Bedford, B. C., 1974: The use of otoliths for age determination. In: The Ageing of Fish. Ed: T. B. Bagenal, Unwin Brothers, Surrey. pp. 114-123.

Author's address: Dr J. G. Pajuelo, Departamento de Biologia, Universidad de Las Palmas de Gran Canaria, Campus Universitario de Tafira, E-35017 Las Palmas de Gran Canaria, Canary Islands, Spain. E-mail: josemaria.lorenzo@biologia.ulpgc.es 